\title{
Magma dynamics during Gondwana breakup and South Atlantic Ocean opening: high-resolution geochemistry of tholeiitic mafic dykes from the Brazilian Southeast margin
}

\author{
KARINE ZUCCOLAN CARVAS ${ }^{1}$, LEILA SOARES \\ MARQUES ${ }^{1}$, TERESA UBIDE ${ }^{2}$ AND PAULO MARCOS DE \\ PAULA VASCONCELOS ${ }^{2}$ \\ ${ }^{1}$ University of São Paulo \\ ${ }^{2}$ The University of Queensland \\ Presenting Author: karinezc@gmail.com
}

The Lower Cretaceous Gondwana breakup focused on fragile portions of the crust, weakened after older orogenic deformation and faulting events $[1,2]$. The extensional reactivation of former faults and the emplacement of voluminous intrusions led to most of the crustal extension prior to the opening of the South Atlantic Ocean [3, 4]. The vast Serra do Mar dyke swarm, in the Southeast margin of Brazil, is an excellent example of the interplay between intrusive magmatism and the rifting process, and can help elucidate magma ascent, crystallization and mantlecrust interactions during continental breakup.

To constrain magma sources, transport, and storage mechanisms during continental rifting, we investigate two distinct mafic dyke suites from the Northeastern portion of the Serra do Mar dyke swarm, in the Cabo Frio Tectonic Domain. The dykes are tholeiitic dolerites with phenocrysts of clinopyroxene, plagioclase, magnetite, ilmenite, and minor olivine, amphibole and biotite within a microcrystalline matrix of plagioclase, pyroxene and magnetite. We compared chemistry and elemental zoning of fresh clinopyroxene (augite) crystals from both suites to constrain pressures and temperatures of crystallization and track magmatic processes.

Preliminary electron microprobe, thermobarometric estimates and crystal-scale elemental mapping via laser ablation ICP-MS on the clinopyroxenes show that crystals from the more evolved magmatic suite derived from shallower and cooler intermediate chambers and had a regular chemical evolution without significant events of mafic replenishment. Crystals from the more primitive dykes, on the other hand, derived from deeper and hotter intermediate magma reservoirs and crystallized within broader temperature and pressure ranges. Minor and trace element maps indicate a surprisingly complex magmatic system influenced by successive injections of primitive magma, particularly preserved at the borders of thick dykes relative to their central portions. Our data aim to track variations in magma differentiation along distinct magma transport pathways during Gondwana breakup.

[1] Moulin et al., 2010. Earth Sci. Rev. [2] Schmitt et al., 2016. Braz. J. Geol. [3] Daniels et al., 2014. Earth Planet. Sci. Let. [4] Granot et al., 2015. Earth Planet. Sci. Let. 